\title{
Fisherman empowerment and poverty in Pesisir Selatan regency
}

\author{
Karjuni Dt. Maani ${ }^{1}$, Aldri Firnaldi ${ }^{2}$, Hidayatul Fajri ${ }^{3, *}$ \\ ${ }^{1}$ Departement of Public Administration, Padang State University, Padang, 25132, Indonesia
}

\begin{abstract}
Pesisir Selatan Regency' fishermen are a group of people who are the most vulnerable to poverty. One of the actions that can be done by the local government is to conduct fishermen empowerment activities in improving their welfare. Thus, the purpose of this study is to describe the vulnerability of fishermen's poverty and to analyse how far the empowerment program is able to improve the economic condition of fishermen in Pesisir Selatan Regency. This research was conducted by using descriptive qualitative research method. The results show that the poverty of fishermen in Pesisir Selatan Regency is caused by the lack of access and assets they have. In addition, empowerment by the government of Pesisir Selatan Regency is not optimal in developing assets and access so that the condition of fishermen in this regency has not been entirely entities from poverty.
\end{abstract}

\section{Introduction}

The percentage of fishermen poverty is greater than the average of Indonesian population. The Poverty Headcount Index (PHI) of fishermen was 0.28, higher than the average of the Indonesian population of 0.18 . It means that in every 100 fishermen, 28 of them are poor. Meanwhile in national in every 100 people, only 18 are in the category of poor [1].

Pesisir Selatan District is the second longest coastline in West Sumatra province which is $278.2 \mathrm{~km}$ and with 14,517 population [2]. In addition, Pesisir Selatan district has the highest number of fishermen in West Sumatra province. Stiglitz [3] said often natural resources inversely with the benefits that society feels, but it becomes a kind of "curse" that trapping people in poverty (Paradox of Planty).

This can be seen from the fishermen condition in Pesisir Selatan Regency, where almost 80\% have low prosperity level (Pesisir Selatan Regency's Statistic Data Center, 2017). In fact, Pesisir Selatan has a large potential of 95,000 tons/year of fisheries, consisting of 14,457.09 tons of Big Pelagic fish, 19,550.91 tons of small Pelagic fish, 60,453.73 tons of Demersal fish and 556.2 tons of shrimp, and also there are export quality of Tuna (kkji.kp3k.kkp.go.id, accessed May 16 ${ }^{\text {th }}$, 2017). However, it becomes an irony where the production of fishermen of Pesisir Selatan Regency is only 1,873.21 ton/year (PPP, 2017).

Several earlier literature attempts to explain the difficulties in enhancing the prosperity of fishermen, It comes from two aspects internal and external factors. Where the internal factors are fishermen capacities such as unproductive family members $[4,5,6$,$] , limited access$ of education $[7,8]$, minimum access to the modern
The fisherman is identical to the poverty [9]. The technologies [10, 11], and insufficient fund [12]. In addition from the external factors are the limited potentials of marine resources that fishermen can use [13], intensive competition, market mechanisms, bargaining power in the presence of middlemen, the state of fishery port infrastructure, and the jurisdiction of autonomous regions are additional burdens which further aggravates the situation.

However, there is only a little who see the inability of fishermen to improve their prosperity is also caused by the failure of the government to develop the capacity of fishermen through empowerment programs. For all this time, empowerment is often used by the government as a "magic spell" which when used is capable of making changes. In fact, the implementation of empowerment also often does not give the effect as expected [14].

Based on research by Dt. Maani, et al [15] indicates that the Pesisir Selatan Regency Government is the one that most influence the success of empowerment activities that have been and will be done. While the empowerment conducted by the Pesisir Selatan Regency government often only a routine project and unsustainable programs. While in implementing the empowerment program the government does not involve other parties. Nevertheless, there has never been a study to see the achievement of empowerment program which is done from the perspective of increasing the prosperity of the fishermen.

In fact, according to Tuwo [16] there are at least five approaches in the empowerment of fishermen that need to be developed in order to run effectively:

1) Development of alternative livelihoods;

2) fund access;

* Corresponding author: hidayatulfajri28@gmail.com 
3) technology access;

4) markets access;

5) Development of collective action.

These five approaches are implemented with genuine attention to the aspirations, needs, revenues, and community's potential resources.

Several studies $[17,18,19]$ indicate that empowerment failure is caused by :

1) Not understanding the problem's root cause failure in completing it;

2) Solutions tend to be in the form of one-way government-derived and expert studies but tend to ignore community participation;

3) The desired result is often the improvement, not the innovation ;

4) The solutions offered tend to minimize the various variations that appear;

5) Used High Modernism approach;

6) Empowerment programs often change over time;

7) Often the created status quo.

Our initial proposition is that the existing fishermen empowerment programs have not been maximized, because of the government's failure to understand the causes of the vulnerability of people's poverty. It caused the fishermen in Pesisir Selatan Regency still in poverty level.

Therefore, this research describes and explores the vulnerability condition of poverty and the success of empowerment program that has been done by Pesisir Selatan Government in improving fisherman's prosperity. Thus, this study will be represented by two questions, how the condition of fishermen in the Pesisir Selatan Regency and whether success or not the fishermen empowerment program in Pesisir Selatan Regency?

\section{Materials and method}

This research used the qualitative method, with the qualitative descriptive approach by looking at the implementation of fishermen empowerment in Pesisir Selatan represented by two places that are represented as the fishing villages that are Sungai Nipah, and Carocok Anau. This research is done in the second fishing village and at the Department of Fisheries Pesisir Selatan Regency. The study was conducted from August to November 2017. In addition, the data collected were primary and secondary data. The data are related to the community empowerment and the condition of fishing communities. The interview technique used in this study is semi-structured that allows researchers to be freer without sticking to the questions that have been set while the sample was determined by using mixed methods between purposive sampling and snowball sampling.

Interviews were done by qualitative observation strategy in which the researcher directly observes the behavior and activity of the Sungai Nipah community. In this observation, the researcher records the activities and also conducted face to face interviews and in-depth interviews with participants to elicit views and opinions from participants. [20].

While the data validation, this research used the triangulation technique. Triangulation leads the author to collect the data in a compulsory manner, using a variety of available data sources. The method of analysis in this study was using interactive analysis model. The interactive analysis model consists of three activities that occur simultaneously: data reduction, data presentation, and conclusion or verification.

\section{Results and discussion}

\subsection{Fisherhermen poverty in Pesisir Selatan regency}

Poverty is not a single thing, but poverty is a social construction which is a multidimensional phenomenon [21]. The World Bank defines poverty as follows:

"Poverty is defined here as a pronounced deprivation of well-being related to lack of material income or consumption, low levels of education and health, vulnerability and exposure to risk, lack of opportunity to be heard and powerlessness. [22]. "

Based on the definition above, this research shows that fishermen in the Pesisir Selatan Regency are a community group that is very vulnerable to poverty.

In identifying the vulnerability of fishermen to poverty in the Regency of Pesisir Selatan developed the Firth study [23] the characteristics cause of fishermen' poverty is: first, the uncertain daily earning. This is often the case with little fishermen who fully lean their daily economy on their catches. In this study, fishermen are generally traditional fishermen because they have boats under $10 \mathrm{GT}$ using robin machines. It makes the fishermen have limited distance to sea (only 1 mile from the shoreline) affecting that they only catch small fishes with low selling point that makes their income be low. As shown in table 1, the average bruto the fisherman got in every catch is only about Rp. 700.000 in maximum.

Table 1. Average bruto the fishermen $<10 \mathrm{GT}$ in every catch

\begin{tabular}{|l|l|l|l|}
\hline \multirow{2}{*}{ No } & \multirow{2}{*}{ Fishermen } & \multicolumn{2}{|c|}{ Income (Rp) } \\
\cline { 3 - 4 } & & Fish Season & $\begin{array}{c}\text { Another } \\
\text { Season }\end{array}$ \\
\hline 1 & Sungai Nipah & $\begin{array}{l}500-600 \\
\text { hundred }\end{array}$ & $\begin{array}{c}100-150 \\
\text { hundred }\end{array}$ \\
\hline 2 & Carocok Anau & $\begin{array}{l}600-700 \\
\text { hundred }\end{array}$ & $\begin{array}{l}100-150 \\
\text { hundred }\end{array}$ \\
\hline
\end{tabular}

The Sungai Nipah' fisherman called it rasaki harimau or uncertain income, where at certain times they can get a lot of catch and in another time not. Nevertheless, based on our survey, the average net fisherman's daily income ranges from $\mathrm{Rp} 18,000$ to $\mathrm{Rp}$ 65,000 it can be concluded between Rp 500,000, - to Rp. 2.500.000, a month.

Secondly, the low level of education of the fishermen and their children makes difficulties in finding other jobs. From the two fishing villages show the average fisherman's education is junior high school graduate and below. The low level of education makes them no choice 
to find another job, although those villages historically are not a fishing village. They trap being a fisherman because of the low of education.

As in the Sungai Nipah, the tradition of sailing began in 2002. Previously the average population there work as farmers and casual workers. However, due to limited agricultural land and not too fertile makes the people of Sungai Nipah then turn the profession into a fisherman. This is because low education makes it difficult for them to be absorbed into formal employment. Thus, it can be said that the fisherman is a profession or job they are forced to choose because of the low education they have.

Its also happening on Carocok Anau though be fishermen were begin a long time ago, it does not make the people can change their profession. Most people in Carocok Anau still work as fishermen today, with most of them still traditional fishermen. By 2017, 680 of its population of a total of 1230 people with productive age of people work as fishermen (see Table 2). So in the same conditions with the Sungai Nipah, became a fisherman who inherited in Carocok Anau caused by low education

Table 2. Carocok Anau's community occupation

\begin{tabular}{|l|l|c|c|}
\hline No & \multicolumn{1}{|c|}{ Job } & Amount & $\begin{array}{c}\text { Percentage } \\
(\mathbf{\%})\end{array}$ \\
\hline 1 & Civil servant & 24 & 1,95 \\
\hline 2 & Police & 7 & 0,57 \\
\hline 3 & Fisherman & 680 & 55,28 \\
\hline 4 & Farmers & 93 & 7,56 \\
\hline 5 & Traders & 37 & 3,00 \\
\hline 6 & Unemployed & 89 & 7,24 \\
\hline 7 & Others & 300 & 24,39 \\
\hline
\end{tabular}

Third, non-durable products should be marketed immediately. This creates a high dependence of the fishermen on the traders or collectors of the catch so this trader or collector can be charged below the market price that should. In the two villages shows that. The cause is the fishermen or groups of fishermen do not have cold storage (refrigerator) used to accommodate the fish to be durable. So that the fish should be sold as soon as possible until it landed.

Another way to avoid the loss is by marinating the fish and dry it as shown in figure 1. Carocok Anau' community dots his thing but this process is depended on the sun. If the fishes do not dry in two or three days, the fishes will be rotten and cause another loss.

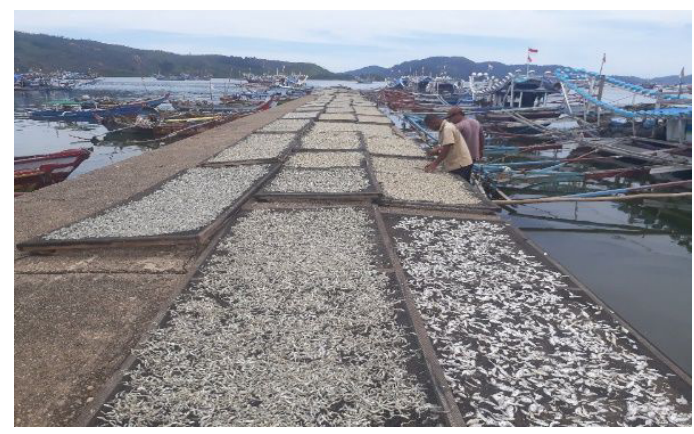

Fig. 1. Carocok Anau's community was marinated and dry the fishes.
This condition shows the loss is a common thing. The overwhelming dependence on natural factors confirms how vulnerable the condition of the fishermen is and makes it difficult for them to get out of the poverty ring.

In fact, at certain times during the fish season, the catch of fishermen has a surplus that can be utilized if the fishermen have facilities for it, such as Cold Storage. However, all this time, the fishermen sell the fishes at the low price to avoid a greater loss This condition then resulted in fishermen do not having a surplus of production although sometimes they have abundant production.

Fourthly, the amount of capital that must be spent in fishery business, causing fishermen to prefer to move to be a small fishery business and also become fisherman labor. The majority of fishermen in these three fishing villages are small fishermen with fishing gear below 30 gt. The average fishing gear that uses in Carocok Anau is 70 -gill nets with engine capacity below $10 \mathrm{gt}$, 67 charts (fig. 2 and fig. 3). So is the Sungai Nipah, all of their boats are just under $10 \mathrm{gt}$. The difficulty of acquiring modern fishing gear is due to the high price of the fishing gear. For one fishing gear measuring under $10 \mathrm{gt}$ is worth 40-50 million rupiahs. In addition to getting to the Exclusive Economic Zone, where economically valuable fish are found, should be is gear-shaped liner with a capacity above $30 \mathrm{gt}$.

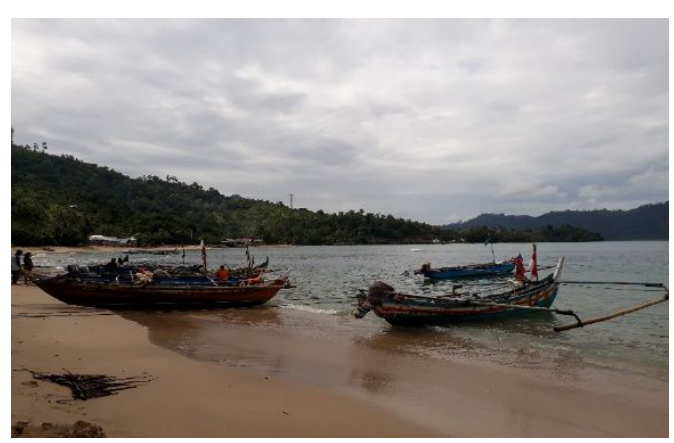

Fig. 2. 7 GT boat of Sungai Nipah' fishermen

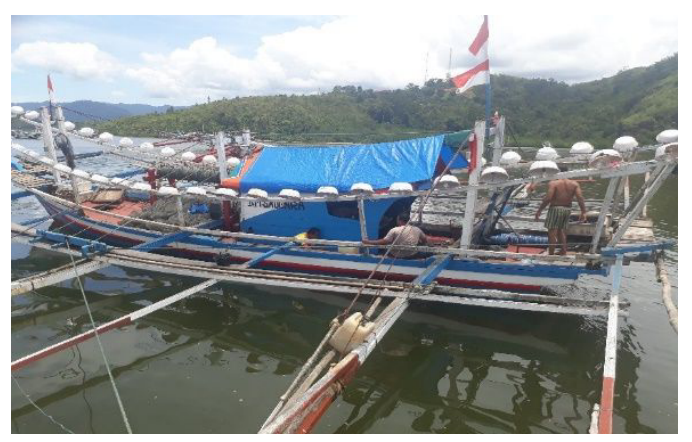

Fig. 3. 10 GT boat of Carocok Anau' fishermen

These four factors are important factors that make it difficult for fishermen to get out of poverty. Therefore, fishermen in the three villages are fishermen who are categorized as small fishermen who are fishing by using traditional and simple equipment and not much touched by modern technology. Affordability of territory in fishing is narrow only 1-2 miles from the shoreline to 
make their access to fish that have high economic value was limited. This is what distinguishes traditional fishermen from modern fishermen, where traditional fishermen do not have the ability to compete with modern fishermen. Thus, traditional fishermen experience the process of marginalization and become victims of competition in the fishery sector.

Thus, if pursued, there are two main things that cause the vulnerability is limited fishermen to access, both access to capital, access to fishing areas, access to technology, access to markets, and also access to education. In fact, the limitations and inequalities of access owned by individuals or communities directly implicate the level of poverty suffered [24, 25, 26].

In addition, due to limited assets, limited fishing gear (ships, boats, charts, etc.), which are still traditional fishing gears, the limitations of supporting assets, such as cold storage, fishing tools, and the limitations of social capital, such as the existence of collective action also cause poverty. Gamble and Prabhakar [27] argue that without an emphasis on assets, people will never get the maximum opportunity to realize their potential and leave poverty.

Therefore, in order to against poverty, the expansion of the distribution of assets and access becomes an important thing to do. Due to the distribution of assets and access is closely linked to the opportunities, preferences, diversity, and fulfillment of individual needs within the wider community. It is added that to see poverty as a multidimensional phenomenon, asset, and access building is an important step to reduce poverty [28].

Although the Pesisir Selatan Regency government has started empowerment program for fishermen since 2004 and in 2011 for cultivation fishermen, the success of the empowerment has not been optimal in uncovering the causes of the vulnerability of fishermen's poverty, the more success and failure will be discussed in section 3.2.

\subsection{Success and failure of fishermen empowerment in Pesisir Selatan regency}

Empowerment is defined as a process of increasing personal, interpersonal, or political power so that individuals, families, and communities can take action to improve their situation. Thus, empowerment is seen as a mechanism by which people, organizations, or communities regain control over their affairs [29, 30].

Thus, the empowerment of fishermen is interpreted as a process of rebuilding the social, political, and economic capacities of individuals, families, and fishermen so that they are able to have rights over their affairs and interests.

In the process of rebuilding the capacity, the existence of assets and access becomes an important thing to note. The existence of the assets and such access in accordance with what was presented by Tuwo [16] which states that there is at least five empowerment approaches toward fishermen need to be developed so that it can be successful empowerment. That is;

1) Development of alternative livelihoods;
2) Development of collective action;

3) Access to funding;

4) Access to technology;

5) Access to the market.

Thus, based on the concept developed by Tuwo [16], then the Pesisir Selatan Regency government in carrying out the empowerment is still targeting the development of assets that are the development of alternative livelihoods and the development of collective action. While efforts to provide access, in the form of access to capital, technology, and the market has not been done optimally so that it becomes not determinant in the success of fishermen empowerment.

The results show that from the development of these assets, of the three Nagari/ villages, which were successfully performed only in the Sungai Nipah while in Carocok Anau empowerment tended to fail. In the Sungai Nipah, the success of fishermen empowerment is characterized by the successful development of alternative livelihoods that are managed collectively.

The success is seen from the decrease of poverty of society. The number of poor people in the Sungai Nipah is currently relatively low, with only 42 people (Data of Rice Recipient of Raskin Nagari Painan Selatan, 2017) dominated by odd workers, and farmers without own land or laborers. Data from Nagari show surprises, ie none of the people who are classified as poor are living as fishermen.

"Here, fishermen welfare are much improved. None of them are still receiving Raskin rice (rice that provides for poor family). Even there (fishermen) were given rice Raskin but rejected." (Interview with

Head of Painan Selatan Nagari, September 7, 2017)

Whereas, in 2010, the number of poor people in Sungai Nipah was still relatively very high, reaching $70 \%$ of the population. The massive decline in the number of poverty due to the formerly poor categorized fishermen slowly started the entity of poverty. This is as quoted from the interview of the following researchers:

"People of Sungai Nipah when compared to the year 2010 before the existence of grouper cultivation and then improvement of fishing boats, which used to only use the traditional boat, relatively improved its economy Due to the people are mostly fishermen". (Interview with Sungai Nipah fisherman chief, 22 September 2017)

Improving economic conditions in Sungai Nipah is contributed by the increasing economy of the fishermen. Previously, the Sungai Nipah fishermen had a high dependence on sea catch, the use of simple equipment while fishing and the absence of alternative livelihoodsbecause some fishermen did not have agricultural landor side livelihoods that could provide additional income into a factor that trapped fishermen in poverty.

The development of alternative livelihoods in the Sungai Nipah is implemented with the consideration that coastal resources in general and capture fisheries have been particularly stressful and degraded. Thus, the need for a breakthrough in order to the fishing community does not lose livelihood or at least decrease income in famine time. 
The Pesisir Selatan Governance initiative by providing grouper fish seedlings to be cultivated in 2010 can be seen as a diversification effort of the Sungai Nipah fishing business. Thus, the fishing community does not simply expect the results of the day-to-day fishing.

An effective strategy can be seen in the increase in the amount of fishermen income. If only by relying on the income as a fisherman, the gross income of the Sungai Nipah fishermen ranges from 500 thousand during 'fish season' and only 100 thousand to 150 thousand while dragging fish. But with the cultivation of grouper, the community has a relatively large amount in fishing time. In September 2017, the 4th time harvest fisherman of the Sungai Nipah in 2017, combined gross revenue of 24 fishermen was Rp. 318.320.000, with the lowest income of Rp. 4,560,000 and the highest Rp. 37.320.000. The following table 3 shows the gross income of Sungai Nipah Fishermen from grouper fish cultivation per year.

Table 3. Gross income of Sungai Nipah's fishermen from grouper fish cultivation per year

\begin{tabular}{|c|c|}
\hline Year & Total Amount (Rp) \\
\hline 2011 & $9,500,000$ \\
\hline 2012 & (not recorded) \\
\hline 2013 & 398.750 .000 \\
\hline 2014 & $156,000,000$ \\
\hline 2015 & 555.247 .000 \\
\hline 2016 & $955,367,000$ \\
\hline 2017 & 1.244 .244 .000 \\
\hline
\end{tabular}

Source: Sungai Nipah cultivation fishermen group, 2017

In the Sungai Nipah, there is no distinction between traditional fishermen and cultivated fishermen. Every fisherman also cultivates as the fisherman and vice versa. Therefore, the work system carried out by Sungai Nipah fishermen is to go to sea as a source of income per day, while the cultivation into an investment they can receive every 3 to 4 months, each harvest time.

Management of fish farming is done collectively through fishermen groups. Empowerment through the development of collective action is synonymous with the development of cooperatives or groups of joint ventures [10]. In the Sungai Nipah, there is a group of traditional fishermen and 16 groups of fishermen. The working system of fish cultivation in the Sungai Nipah is by managing collectively but doing individually. That is, any decision related to what will be done, when, and how to do is taken together through the deliberation of fishermen groups, but at the time of execution, each individual must work on the part that has been destined for him. So, what is demanded first is the responsibility to oneself.

On the other hand, the results show that empowerment in Carocok Anau has not been able to develop alternative livelihoods of fishermen. In fact, the Pesisir Selatan Regency government has done the same strategy by developing fish farming.

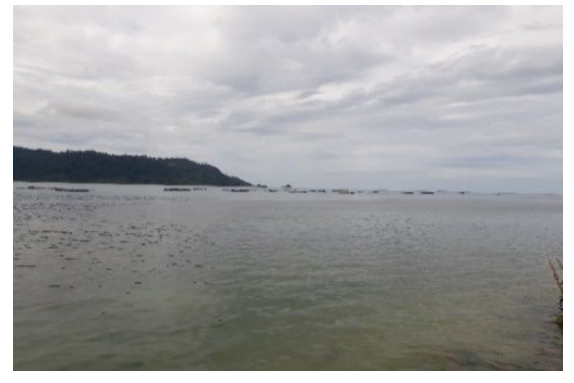

Fig. 4. Fishpond of grouper cultivation at Sungai Nipah

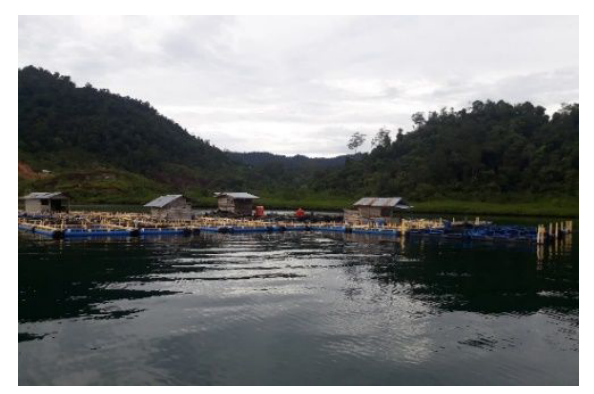

Fig. 5. Fishpond of grouper cultivation at Carocok Anau

Nevertheless, the development sought by the government in the form of substituting and supporting the main livelihoods as a fisherman in the form of cultivation of freshwater fishery or sea water still shows unseen developments, instead of bringing the community to a deeper poverty condition because of the loss to be borne. This is due to the failure of fishermen in developing fishing groups. Developing cooperative or joint venture group that only procedural shaped and centered to the government is not an initiative of the fishermen.

Besides the development of alternative livelihood and the collective action, the provision of access is also important in empowerment, but unfortunately, the Pesisir Selatan Regency government as a stakeholder who has the ability in facilitating the provision of capital is not optimal.

In the fishery sector, access to capital becomes an important point, because the average fisherman has limited fund. Thus, the government can facilitate the process of empowering the fishermen. Difficulty in obtaining capital because of the nature of fishing business seasonality, uncertainty, and high risk often a reason for banks that serve to provide a fund for this business are reluctant to disburse capital [10], so the government should be able to be a facilitator in the provision of fund for fisherman.

Efforts to empower can also be done through the improvement of fishing technology. In Pesisir Selatan Regency, efforts to increase community access to technology have not been widely implemented especially the post-production technology and marketing phases. Existing technological improvements are only the replacement of ships from wooden ships to fiber boats and the use of outboard engines which previously used robin machines for the fishing sector. 
This is because of the high price of these technologies and the need for maintenance, technical use. Thus, the involvement of other sectors that have the capability will be a technology solution. In the cultivation sector, fish seeds are supplied from BBIP (Fish Seed Center) Teluk Buo and for post-production, the fish directly send into the market system.

Market access is an empowerment successful factor and also can the main obstacles when the market does not develop. The fish which catch by the traditional fishermen were bought by the trader who comes every morning while the collecting companies buy the cultivated ones.

The difficulty of fishermen in Pesisir Selatan Regency, especially the cultivation fishermen, is selling the fish directly to the exporter. The reason is the quota set by the export company can not be fulfilled. The exporter sets 20 tons quota of fishes while the production is only 3 tons.

In conclusion, the interpretation that can be drawn from empowerment conducted in Pesisir Selatan Regency is that changes in prosperity can be done by improving the availability of assets and access for fishermen. Thus, fishermen can develop themselves, and their environment. It happens to the Sungai Nipah's fishermen, where they can utilize the development of assets, either in the economic or social assets so so that improve their prosperity. This, in line with the focus on empowerment, is to re-establish confidence, because the confidence that will contribute to individual, societal and social change. Thus, for individuals to engage in social life actions, they must first develop a sense of critical awareness [5, 6, 8, 27]. However, it will not be achieved if the empowerment that runs only one direction, government-centric. The active role of the community as an empowered party becomes a very important point so that community empowerment does not end in the tactical programs of the government whose benefits are not perceived by the community in a sustainable manner as happened Carocok Anau.

\section{Conclusion}

The empowerment of fishermen in Pesisir Selatan Regency has been going on from 2004 to traditional fishermen and in 2011 began to develop the empowerment into marine aquaculture which aims to develop the capacity of fishermen to increase their life.

Identification of the vulnerability condition of fishermen in Pesisir Selatan Regency indicates that the vulnerability of poverty is caused by several things, such as a) daily income; b) the low level of education caused difficulty in finding other job; c) the products do not last long; d) the amount of capital in fishery sectors causing the fishermen prefer to do a small fishery and become fishermen laborers.

Based on the non-optimal empowerment program, researcher assumed that in order to increase the fishermen prosperity the government, private, civil society, and various sectors should collaborate to give an access and help the fishermen to increase their production capabilities and assist the asset ownership in Pesisir Selatan Regency.

\section{References}

1. Marine and Fisheries Economic Research Center. Formulation of Joint for Fishermen's Poverty Alleviation Jakarta. (2006).

2. Mariani, N. H. Aimon. S. U. Sentosa. Analysis of Production and Efficiency of Sea Fish Fishermen's Machine Chart in Koto XI Tarusan South Pesisir. Kajian Ekonomi Journal, July, Vol III, No.5. (2014).

3. J. Stiglitz. Making Globalization Work: Menyiasati Globalization Towards a Fairer World. (2007).

4. I. Indarti. Model for Improving Coastal Community Welfare through Strengthening Sustainable Fisheries Cooperative Institutions. Dinamika Ekonomi \& Bisnis Journal Vol. 12 No. 1. (2015).

5. L. Rodriguez-Takeuchi. K. S. Imai. Food price surges and poverty in urban Colombia: New evidence from household survey data. Food Policy. 43, 227-236. (2013).

6. M. Lawhon. Urban Poverty in the Global South: Scale and Nature. International Journal Of Urban and Regional Research. 38 (1). (2014).

7. I. S. Wekkea. A. Cahaya. Fishermen Poverty and Survival Strategy: Research on Poor Households in Bone Indonesia. Procedia Economics and Finance 26, 7-11. (2015).

8. P. S. B. Jackson. The Crisis of the Disadvantaged Child: Poverty Research, IQ, and Muppet Diplomacy in the 1960s. Antipode. 46 (1), 190-208. (2014).

9. H. Wibowo. E. S. Bahri. P. P. Harto. Optimizing the Role of the Batam Fishermen Community in Economic Development. SOSIO DIDAKTIKA: Social Science Education Journal, 3 (1). (2016).

10. A. H. Buang. J. A. Hamzah. Y.S. Ratnawati. The promise of community - based fishery resource management. World Applied Sciences Journal. 13, 104-109. (2011).

11. M. B. Katz. The Land of Too Much: American Abundance and the Paradox of Poverty. Journal Of American History. 100 (3), 900-901. (2013).

12. OECD. Competition and Poverty Reduction. Directorate for Financial and Enterprise Affairs. (2013).

13. A. Satria. Beach and Sea for People. Bogor: IPB Press. (2009).

14. L. Soeprijadi. E. Yuli. E. Susilo. Rudianto. Fishermen Community Economic Empowerment through Joint Development Business Group in Cirebon City. International Journal of Marine Science, Vol.3, No.35, 278-284. (2013).

15. K. Dt. Maani. A. Frinaldi. H. Fajri. Fisherman Community Empowerment Model in the Nipah River. Proceedings of the National Seminar on Challenges and Prospects of Public Administration in Achieving Sustainable Development in 2030. (2017). 
16. H. A. Tuwo. The Management of Coastal and Marine Ecotourism: Brilian Internasional. (2011).

17. E. De Bono. New Thinking for the New Millennium. CA: New Millennium Entertainment. (2000).

18. G. Kartasasmita. Power and Empowerment: $A$ Study of Knowing the Concept of Community Empowerment Jakarta: National Development Planning Agency. (1996).

19. IDEO. Human Centered Design. IDEO. 2010.

20. J. W. Creswell. Research Design Qualitative, Quantitative, and Mixed Approach. Yogyakarya: Pustaka Pelajar. (2012).

21. H. Fajri. Forest Management and Community Poverty Policy. Natapraja Journal Vol. 3. No. 1, 116. (2015).

22. World Bank. A Revised Forest Strategy for the World Bank Group. Washington, D.C: World Bank. (2002).

23. S. K. Poverty and Social Disparity: When the Development Doesn't Prefer to the Poor. Surabaya: Airlangga University Press. (2005).

24. M. Mkondiwa. C.B.L Jumbe. K.A Wiyo. PovertyLack of Access to Adequate Safe Water Nexus: Evidence from Rural Malawi. African Development Review, Vol. 25, No. 4, 537-550. (2013).

25. R. Ingwe. Why Access to Electricity is a Big Deal for Nigeria's Development and its Linkages to Poverty, Security, and Disease. Volume 5 (19) Issue 1. Valahian Journal of Economic Studies. (2014).

26. S.S. Sellamuttu. T. Aida, R. Kasahara. Y. Sawada. D. Wijerathna. How Access to Irrigation Influences Poverty and Livelihoods: A Case Study from Sri Lanka. The Journal of Development Studies. Vol. 50, No. 5, 748-768. (2014).

27. A. Gamble. R. Prabhakar. 2005. Assets and Poverty. Theoria: A Journal of Social and Political Theory, No. 107, Power, Poverty and the Democratic Nation, 1-18. (2005).

28. J. A Adjei. T. Hossain. Asset Building and Poverty Reduction In Ghana: The Case Of Microfinance. Savings and Development, Vol. 33, No. 3, 265-291. (2009).

29. J. Rappaport. In praise of paradox: a social policy of empowerment over prevention. Presidential address to the Division of Community Psychology of the American Psychological Association. The American Journal of Community Psychology, 9, 125. (1981).

30. J. Rappaport. The Power of Empowerment Language. Social Policy, 16, 15-21. (1985).

31. C. Kieffer. Citizen empowerment: A developmental perspective. In J. Rappaport, C. Swift, \& R. Hess (Eds.), Studies in empowerment: Toward understanding and action, 9-36. New York: Haworth Press. (1984).

32. C. Swift G. Levin. Empowerment: An emerging mental health technology. Journal of Primary Prevention, 8(1-2), 71-94. (1987).

33. E. Pecukonis. S. Wenocur. Perceptions of self and collective efficacy in community organization theory and practice. Journal of Community Practice, 1(2), 5-22. (1994).

34. M. Zimmerman. J. Rappaport. Citizen participation, perceived control, and psychological empowerment. American Journal of Community Psychology, 16, 725-750. (1988). 